\title{
'n Sosiaal-sielkundige en kognitiewe benadering tot die ontwikkeling van 'n kledingverbruikersbesluitnemingsmodel
}

\author{
Helena M de Klerk
}

\begin{abstract}
Many academics and researchers underline the fact that textile training and research in merchandising do not emphasise the theory enough. This may partly be because retailing and marketing, and consumer education as applied fields, have not stressed basic theory in recent years. The role theory can play in solving practical problems has also been misunderstood.

Merchandising and consumer education researchers have to collect and organise their own theory base. This theory base should incorporate root disciplines in the social sciences plus major contributions from marketing and business management, other fields of home economics, and in this case various textile and clothing areas.
\end{abstract}

The choice of a new product requires decisions by the consumer. According to clothing theorists and researchers in clothing consumer education, these decisions are usually made in the clothing store at the point of purchase. The decision-making process consists of five stages, namely the awareness stage, the interest stage, the evaluation stage, the trail stage and the adoption stage.

Clothing research indicates that clothing consumers seek information, compare alternative choices and make decisions at the point of purchase. It is important to know what information the clothing consumer seeks and uses in coming to a decision. It is also important to know what types of information are utilised by different consumer target groups. Researchers and academics should be aware of different patterns of seeking information, based on lifestyles, psychological characteristics and cognitive ability in the target groups. This information should be integrated and combined with the basic theory from related fields to develop a social-psychological and cognitive clothing consumer decision-making model to be used by academics and researchers in clothing consumer education programmes.

In the field of clothing, the symbolic interactionism and a cognitive perspective have been successfully combined with theory in the fields of consumer behaviour to address a wide variety aspects, influences and problems in the field of clothing consumer education and in clothing consumer research. All the data should be integrated into a social-psychological and cognitive framework for clothing consumer decision making.

- Prof HM de Klerk

Department of Home Economics

University of Pretoria

\section{AGTERGROND}

Volgens Sproles en Burns (1994:1) is die enigste saak waaroor daar in die moderne ontwikkelende wêreld konsensus kan wees, voortdurende en vinnige verandering. Dit blyk ook uit die vinnige verandering in die meeste mense se voorkoms. Vinnige verandering en kort modesiklusse is aan die orde van die dag. Volgens du Plessis et al (1990:3), Sproles en Burns (1994:xiii) en ander teoretici en skrywers op die gebied van kleding en verbruikersgedrag, is dit ' $n$ teken dat verbruikers vinnig verander en deur ' $n$ magdom psigologiese, sosiale, ekonomiese en ander invloede beïnvloed word.

Verbruikersgedrag op die gebied van kleding is nie " $n$ eenvoudige proses nie. Dit kan ook nie aan verbruikersgedrag op ander gebiede gelyk gestel word nie. Sproles en Burns (1994:xiii) stel dit duidelik: "Fashionoriented consumer behaviour results from a multitude of behavioral processes and is among the most complex acts of consumer behaviour." Dit mag moontlik wees waarom daar in die verlede heelwat omtrent verbruikers en verbruikersgedrag in die algemeen geskryf is, modeteorieë ontwikkel is en aandag gegee is aan sosiaal-sielkundige, kognitiewe en ander invloede op mense se kledinggedrag. Maar weinig teoretici, veral in Suid-Afrika, wou hul hand waag aan die ontwikkeling van ' $n$ goed geïntegreerde raamwerk vir verbruikersbesluitneming ten opsigte van kleding.

Teoretici, akademici en navorsers pleit reeds die afgelope dekade dat mense se kledinggedrag kontekstueel vanuit die vertrekpunte van versoenbare teoretiese perspektiewe bestudeer moet word (Kaiser, 1983, 1984; Davis, 1984; Nagasawa et al, 1989; Damhorst, 1991; Rudd, 1991). Sedert die tagtigerjare vra kledingkundiges soos Kaiser (1983-1984) en Lennon en Davis (1989(a) en (b)) vir ' $n$ kombinering van sosiaal-sielkundige perspektiewe soos die simboliese interaksionisme en ' $n$ kognitiewe benadering vir die sinvolle bestudering van mense se kledinggedrag. Volgens die werke van skrywers en navorsers soos Davis en Lennon (1991) en Drake et al (1992:15), lyk dit asof die simboliese interaksionisme, 'n kognitiewe perspektief en die teorie rondom kleding en verbruikersgedrag in die algemeen sinvol gekombineer kan word in die ontwerp van ' $n$ model en raamwerk vir kledingverbruikersbesluitneming.

So ' $\mathrm{n}$ raamwerk behoort vir die kledingnavorser en bemarker van waarde te wees. Dit sluit aan by die siening van Winakor (1988:31-35) wat die behoefte 
aan ' $n$ goed geïntergreerde en teoreties gefundeerde raamwerk vir verbruikersnavorsing op die gebied van kleding ondersteun. "Textiles and clothing instruction and research in the merchandising area have not emphasized theory. This is partly because retailing and marketing, as applied fields, have not stressed basic theory in recent years. Also, there is misunderstanding of the role that theory can play in solving practical problems. Textiles and clothing merchandising researchers need to collect and organize their own theory. This should be built on root disciplines in the social sciences plus major contributions from business administration, other fields of home economics, and various textiles and clothing areas".

Die doel van dié studie is dus om 'n geïntegreerde en teoreties gefundeerde raamwerk vir verbruikersbesluitneming ten opsigte van kleding daar te stel. Om dit te kan doen word aandag geskenk aan die breë veld van verbruikersbesluitneming, spesifieke verbruikersbesluitneming ten opsigte van kleding asook die simboliese interaksionisme en ' $n$ kognitiewe perspektief as teoretiese vertrekpunte vir die ontwikkeling van so ' $\mathrm{n}$ besluitnemingsraamwerk.

\section{VERBRUIKERSBESLUITNEMING}

Rousseau (1990:42) is van mening dat besluitneming een van die belangrikste aspekte in die bestudering van verbruikers se gedrag is. Verbruikersbesluitneming word volgens Rousseau (1990:43) deur individuele en omgewingsveranderlikes beïnvloed. Die invloed van hierdie veranderlikes op die verbruiker se besluitneming word in Figuur 1 voorgestel.
Volgens die model is dit duidelik dat daar ses veranderlikes ten opsigte van individue is wat hul besluitneming beïnvloed, naamlik behoeftes, motiewe, persoonlikheid, persepsies, leer en houdings. Motiewe is volgens Rousseau (1990:43) die innerlike dryfvere wat mense motiveer en hul gedrag reguleer sodat sekere doelwitte bereik kan word. Hierdie motiewe maak mense bewus van hul behoeftes. Behoeftes word beskou as innerlike kragte wat op spesifieke doelwitte gerig is. Volgens Rousseau (1990:43) is persoonlikheid ' $n$ kombinasie van mense se unieke, individuele kenmerke of geneigdhede wat hulle beïnvloed om op ' $n$ sekere manier op te tree en besluite te neem. Persepsie is ' $n$ proses waarvolgens mense sensoriese stimuli kies, organiseeer en interpreteer ten einde ' $n$ betekenisvolle, koherente prentjie te vorm. Leer verwys volgens Rousseau (1990:43) na die moontlikheid om gedrag te verander as gevolg van sekere ondervindinge in die verlede. Houding is ' $n$ aangeleerde geneigdheid wat tot gevolg het dat mense konstant op dieselfde positiewe of negatiewe wyse op sekere voorwerpe of onderwerpe reageer.

Daar is ook ses omgewingsinvloede wat die verbruiker se besluitneming raak, naamlik kulturele invloede, sosiale invloede, verwysingsgroepe, die gesin, ekonomiese eise en besigheids- en markinvloede. Kulturele invloede is gelowe, norme, waardes en gewoontes wat binne ' $n$ bepaalde gemeenskap geld. Sosiale invloede kan beskou word as kommunikasie in aangesig-tot-aangesig-situasies. Die opinies van vriende of bure of beoordeling deur die portuurgroep is sosiale invloede. Verwysingsgroepe is groepe met wie mense identifiseer en met wie hulle graag vergelyk wil word.

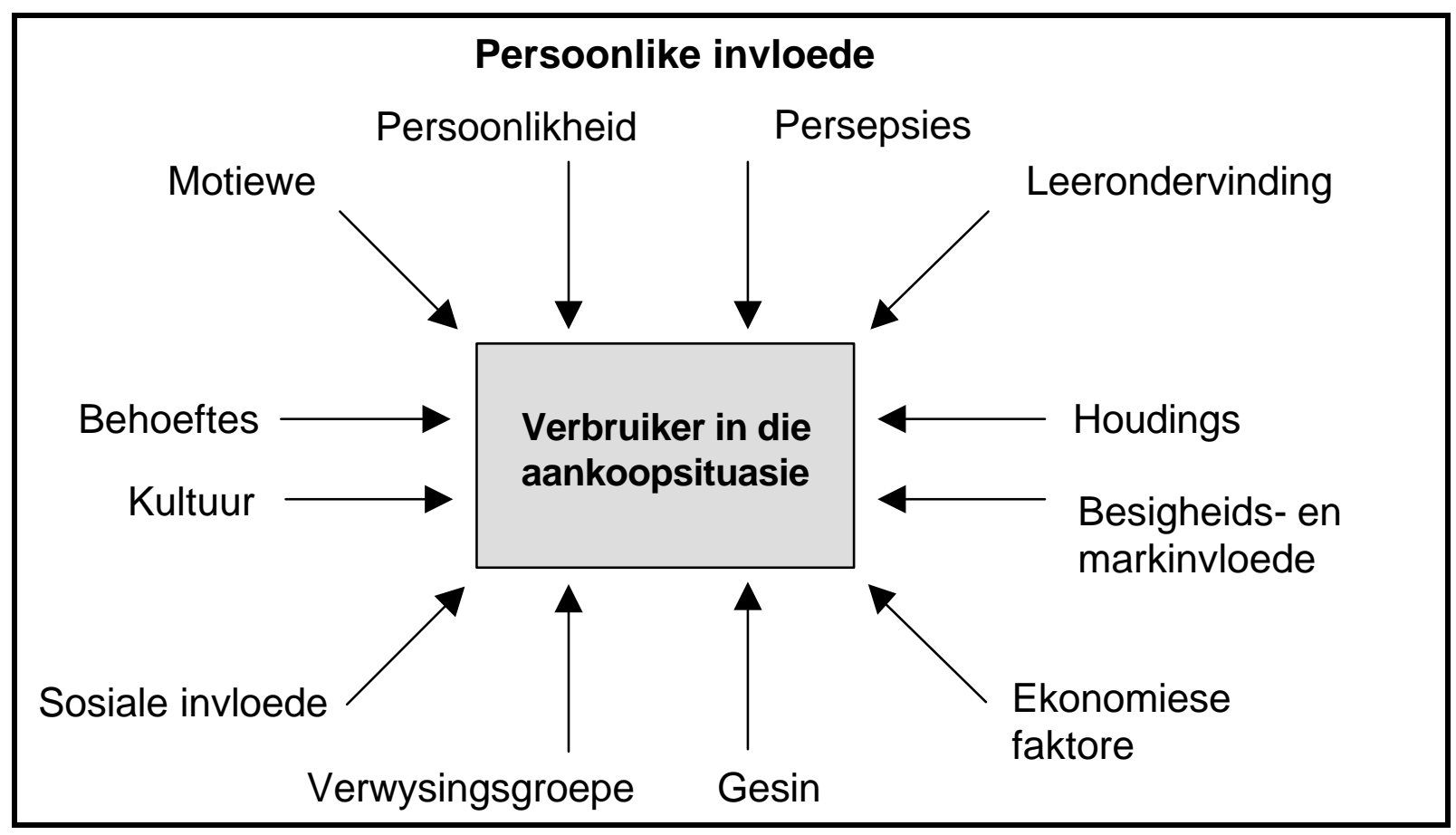

FIGUUR 1: INVLOEDE OP VERBRUIKERSBESLUITNEMING (Rosseau, 1990:44) 
Die gesin se invloed verwys na die invloed van lede van dieselfde huishouding. Rousseau (1990:45) sê dat ekonomiese eise verwys na aspekte soos die beskikbaarheid van of gebrek aan geld of kredietwaardigheid asook na die prys van artikels en die finansiële risiko wat ' $n$ besluit tot gevolg het. Besigheids- en markinvloede is die direkte kontak wat ' $n$ verbruiker met besighede soos winkels, verkoopspersoneel en advertensies het of gehad het.

Besluitneming raak nog ingewikkelder wanneer dit kom by die aankoop van produkte wat ' $n$ hoë sosiale risiko inhou, onder meer kleding. Ten einde die proses te kan verstaan word ses stadia onderskei (kyk Figuur 2) (Rousseau, 1990:47).

Dit blyk duidelik uit die figuur dat die verskillende stadia deur individuele of omgewingsinvloede geraak word. Hierdie invloede kan die verbruiker help of verhinder om tot die volgende stap van besluitneming oor te gaan.

Rousseau (1990:46-56) beskryf die eerste stap in verbruikersbesluitneming as bewuswording van 'n bepaalde produk, in dié geval 'n kledingproduk, en verbruikers se behoeftes word beïnvloed deur:

- eie individuele faktore soos gelowe en voorkeure

- die gesin en verwysingsgroep, byvoorbeeld dat voorkeur aan ' $n$ bepaalde handelsnaam gegee word

- kulturele en sosiale invloede, byvoorbeeld dat voorkoms ' $n$ sekere beeld van sukses of status moet weergee

- ekonomiese faktore, byvoorbeeld dat die verbruiker nie ' $n$ bepaalde kledingstuk op daardie stadium kan bekostig nie

- besigheids- en markveranderlikes, byvoorbeeld dat die verbruiker op daardie stadium nie 'n geskikte kledingstuk kan kry nie.

Sekere meganismes mag in werking tree wat die verbruiker verhinder om ' $n$ besluit te neem:

- 'n Gebrek aan fondse kan 'n probleem veroorsaak.

- Konflik tussen inkomste en persoonlike behoeftes en begeertes kan problematies wees.

- Die gesin of verwysingsgroep kan van die verbruiker verwag om te konformeer wat voorkoms aanbetref, terwyl die kledingstuk wat hy of sy in gedagte het individualisties van aard is.

- Die verbruiker beweeg moontlik in ' $n$ nuwe sosiale omgewing in en voel onseker of sy of haar voorkoms aan die gemeenskap se sosiale waardes voldoen.

Hierdie en ander probleme kan oorkom word as die verbruiker na die volgende stadium van verbruikersbesluitneming oorgaan, naamlik die soeke na en die verwerking van inligting. Ook hier kan verskillende individuele en omgewingsveranderlikes die verbruiker in ' $n$ mindere of meerdere mate ondersteun of verhinder om na die laaste twee stadiums, naamlik respons en na-aankooprespons, oor te gaan.

Assael (1987:169) glo dat verbruikersbesluitneming vertraag word in die geval van hoërisiko-produkte soos kleding omdat die verbruiker gewoonlik meer intens daarby betrokke is. Die vraag is, wat is die menings van navorsers en teoretici op die gebied van kleding?

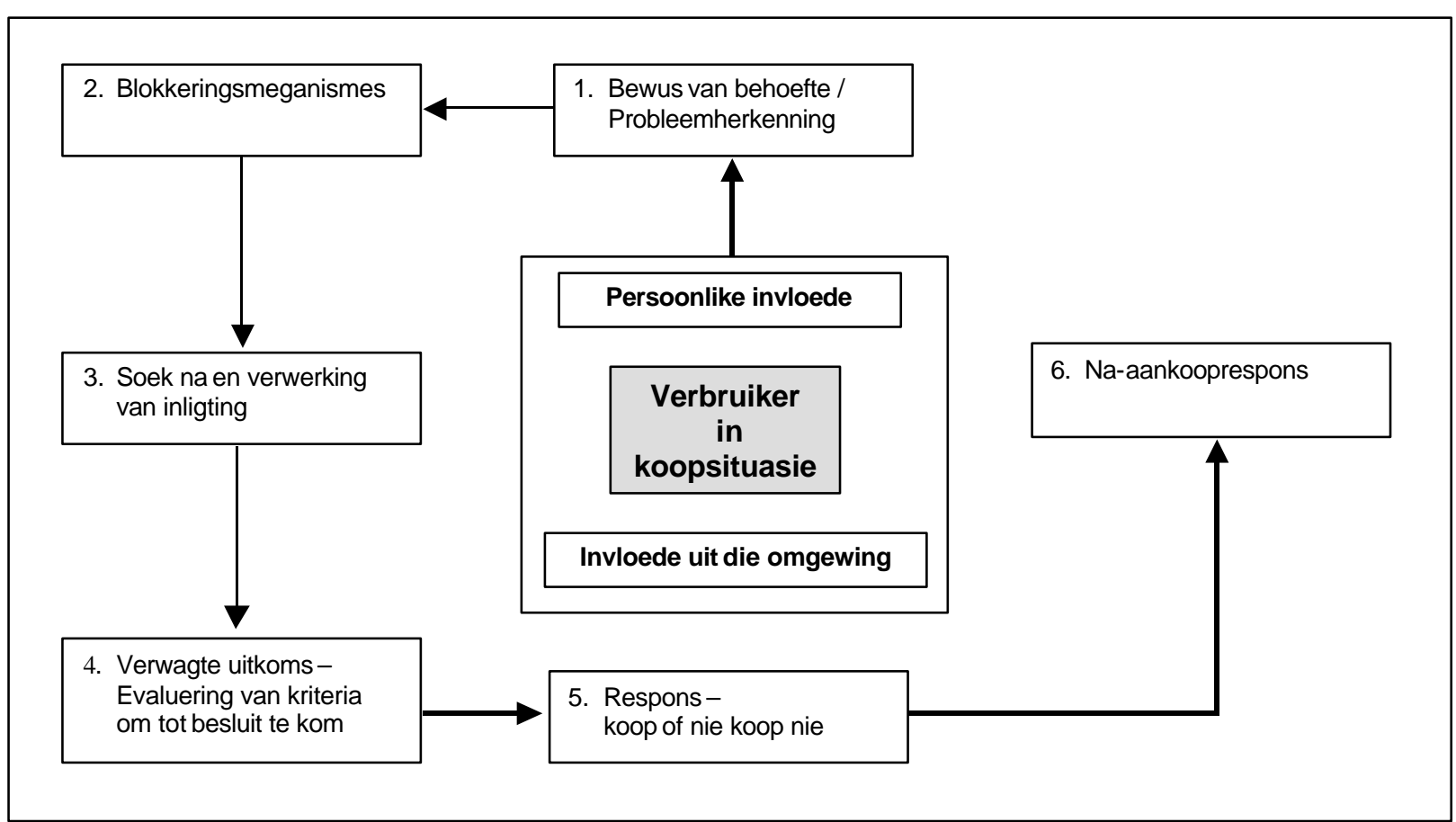

FIGUUR 2: $\quad$ STADIA IN DIE VERBRUIKER SE BESLUITNEMING (Rosseau, 1990:47) 


\section{BESLUITNEMING BY KLEDINGVERBRUIKERS}

Volgens die navorsing van sosiaal-sielkundiges op die gebied van kleding gedurende die afgelope twee dekades is dit duidelik dat kleding ' $n$ integrale deel van mense se lewens vorm. Dit is ' $n$ produk waarby die verbruiker intens betrokke is (Horn \& Gurel, 1981:390-420; Kaiser, 1990:3-27; Drake et al, 1992:15-30; Sproles \& Burns 1994:263-279). Sproles en Burns (1994:264-265) kom tot die gevolgtrekking dat die kledingverbruiker se besluitnemingsproses uit vyf stadiums bestaan en dat daar by elke stadium ander faktore is wat die besluit beïnvloed (kyk Figuur 3).

Die bewuswordingstadium kan met Rousseau (1990:47) se probleemstadium vergelyk word. Reynolds en Darden (1972) en Sproles en Burns (1994:264) is van mening dat mark- en omgewingsinvloede, en spesifiek die massamedia en reklame, die kledingverbruiker daarvan bewus maak dat hy of sy ' $n$ behoefte aan ' $n$ nuwe kledingproduk het.

Sproles en Burns (1994:264) noem die tweede stadium die belangstellingstadium, wat vergelyk kan word met Rousseau (1990:47) se inligtingsoeke en prosesseringstadium. Markinvloede, en spesifiek die massamedia, asook kommunikasie van aangesig tot aangesig as deel van sosiale invloede het ' $n$ groot invloed op die kledingverbruiker se besluitneming.

Derdens identifiseer Sproles en Burns (1994:264) 'n evalueringstadium wat vergelyk kan word met Rousseau (1990:47) se verwagte uitkoms- of evaluering stadium sowel as ' $n$ onderdeel van die inligtingsoeke en -prosesseringstadium. Persoonlike invloede en invloede uit die sosiale omgewing asook die gesin en die verwysingsgroep kan die kledingverbruiker sterk beïnvloed. Mark- en besigheidsinvloede kan ook ' $n$ rol speel.
Die uitprobeerstadium kan met Rousseau (1990:52 53) se responsstadium vergelyk word. Op hierdie stadium het die kledingverbruiker feitlik finaal besluit om wel die kledingproduk aan te koop. Hierdie stadium vind meestal by die aankooppunt plaas met die gevolg dat veral besigheids- en markinvloede, byvoorbeeld in die vorm van die verkoopspersoon se opinie, 'n belangrike invloed op die verbruiker se besluit het.

Sproles en Burns (1994:265) onderskei laastens die aanvaardingstadium. Die kledingverbruiker se persoonlike satisfaksie speel hier ' $n$ groot rol. Navorsing deur Polegato en Wall (1980) bevestig bostaande en beskryf die volgende invloede tydens die verskillende stadiums van besluitneming:

Dit blyk duidelik uit Figuur 4 dat tydskrifte, koerante of televisie die belangrikste bronne van inligting oor nuwe kledingprodukte is of verbruikers bewus maak van nuwe kledingprodukte of die behoefte aan spesifieke kledingprodukte by verbruikers skep. Die massamedia en persoonlike invloede in die vorm van waarneming of bespreking speel ' $n$ belangrike rol in besluitneming tydens die belangstellingstadium. Waarneming en bespreking is ook belangrik tydens die evaluasiestadium. Gedurende hierdie twee stadiums sal die kledingverbruiker moontlik probeer om meer inligting omtrent ' $n$ verlangde produk te verkry deur dit self onder oë te kry of die produk met lede van die gesin of die verwysingsgroep te bespreek of om meer inligting van byvoorbeeld die winkelassistent of verkoopsdame te probeer kry. Wanneer die verbruiker besluit om wel die kledingproduk van nader te beskou, speel besigheids- en markinvloede, byvoorbeeld die winkeluitstalling, etikette, verpakking en verkoopspersoneel, ' $n$ belangrike rol in sy of haar besluitneming. Die verbruiker moet nou finaal besluit of hy of sy die produk wil koop of nie. In die laaste stadium, wanneer die produk aanvaar en gekoop is, moet die verbruiker besluit of dit 'n goeie keuse was

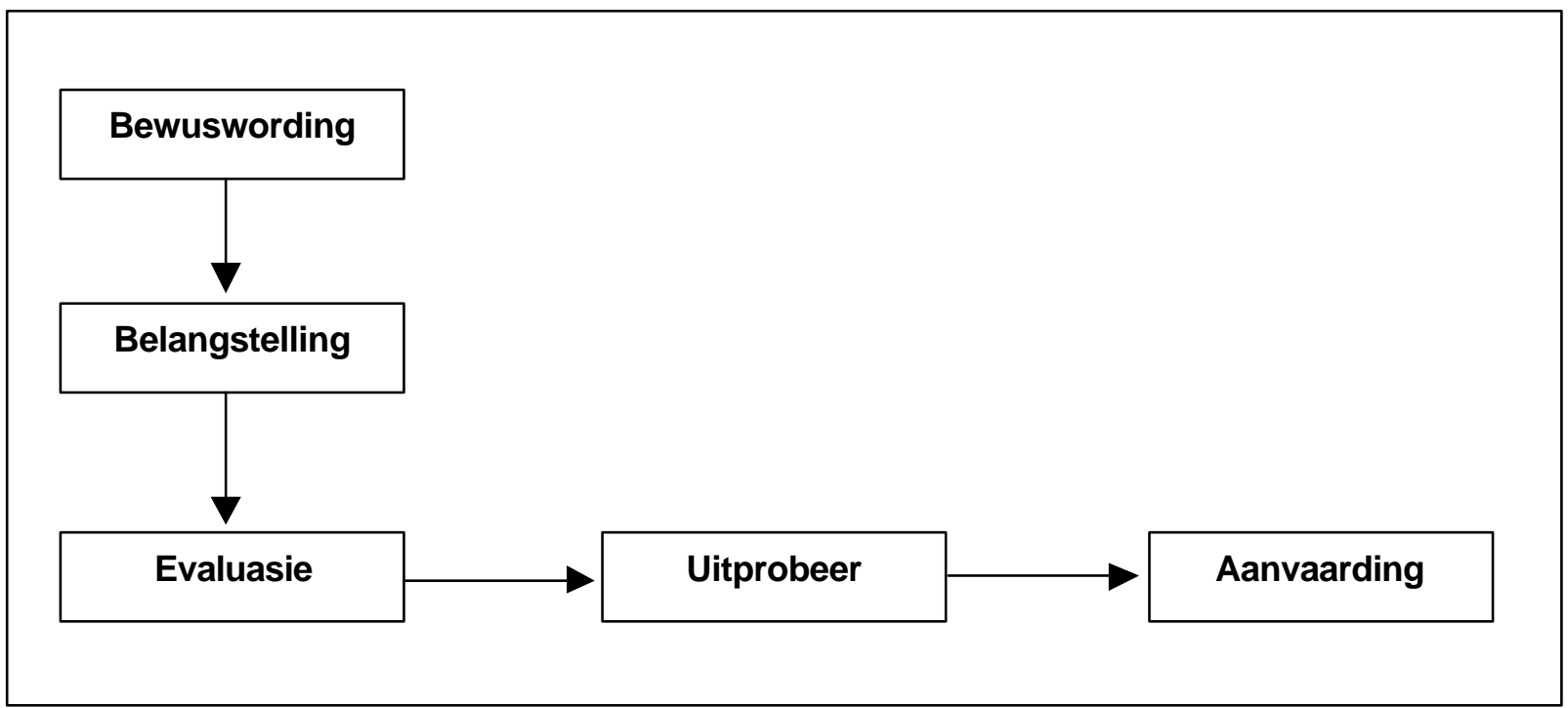

FIGUUR 3: $\quad$ STADIA IN DIE KLEDINGVERBRUIKER SE BESLUITNEMING (Sproles \& Burns, 1994:264-265) 


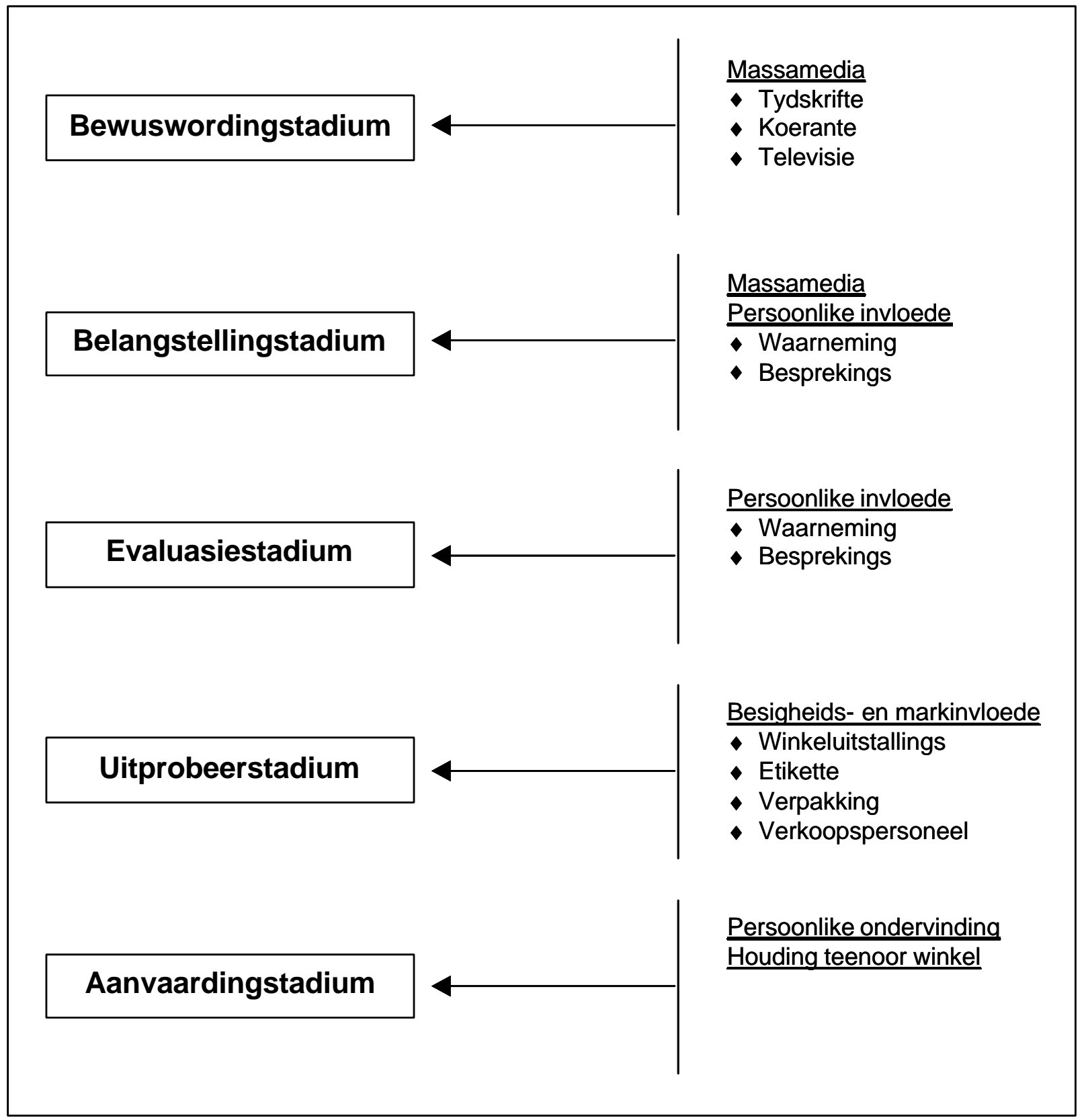

FIGUUR 4: INVLOEDE OP DIE KLEDINGVERBRUIKER SE BESLUITNEMING

(Sproles \& Burns, 1994:267)

en of hy of sy weer so 'n produk sal koop. Persoonlike ondervinding met soortgelyke produkte of vorige ondervinding met die winkel of die verbruiker se verhouding met die verkoopspersoneel is invloede wat tydens hierdie finale stadium ' $\mathrm{n}$ rol speel.

Besluitneming verloop nie vir alle kledingverbruikers op dieselfde manier nie en bykomende faktore kan 'n besluit beïnvloed. Polegato en Wall (1980) voer aan dat daar duidelik onderskeid gemaak moet word tussen modeleiers en modenavolgers. Die soeke na inligting is vir die modeleier belangriker as vir die modenavolger wat dikwels impulsief ' $n$ besluit by die aankooppunt neem. Dit wil ook voorkom asof besigheids- en markinvloede ' $n$ groot rol by modeleiers se besluitneming speel, terwyl persoonlike kommunikasie in die sosiale omgewing, in die gesin en die verwysingsgroep 'n groter rol by modenavolgers speel. Die modieusheid van die kledingproduk in die sin van hoogmode vir die modeleier en mode of massamode vir die modenavolger, is dus belangrik wanneer kledingverbruikers se besluitneming bestudeer word. Dit dui weer eens daarop dat die besluitneming van kledingverbruikers nie aan besluitneming ten opsigte van ander verbruikersgoedere gelyk gestel kan word nie, en dat ' $n$ model wat spesifiek op die kledingver- 


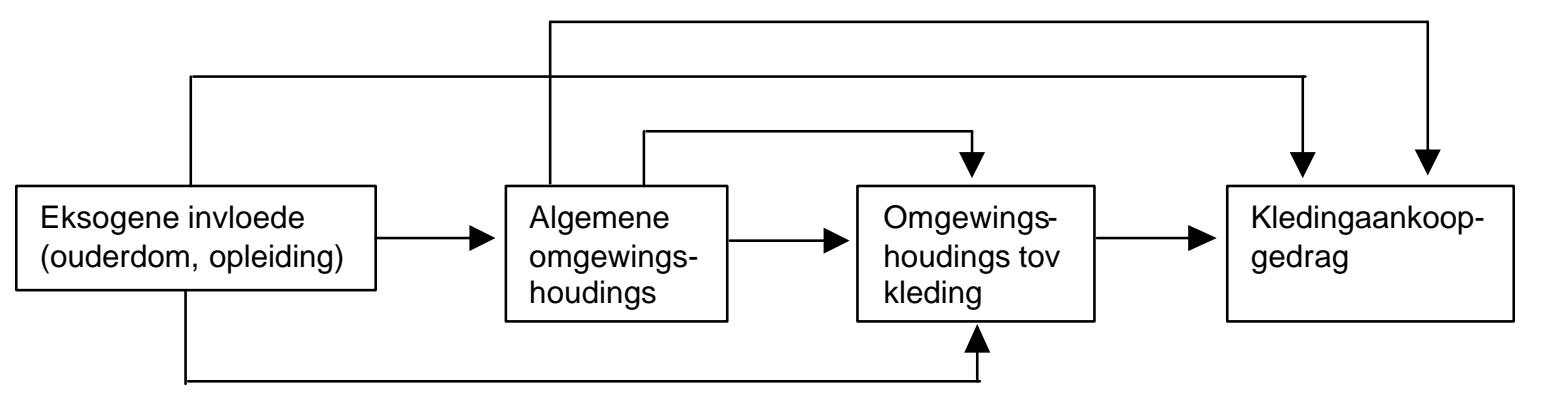

FIGUUR 5: INVLOED VAN HOUDINGS OP KLEDINGVERBRUIKER SE AANKOOPGEDRAG (Butler \&

Francis, 1997:83)

bruiker se besluitneming van toepassing is, vir navorsers van kleding- en verbruikersgedrag van groot waarde kan wees.

Navorsers soos Davis (1987) en Eckman et al (1990) is van mening dat die evaluasie-, uitprobeer- en aanvaardingstadiums vir kledingverbruikers hoofsaaklik in die winkel by die aankooppunt plaasvind. Hoewel kledingverbruikers vooraf ' $n$ besluit neem oor die tipe winkel waar hulle graag koop, die bedrag geld wat hulle kan uitgee en die tipe kledingstuk waarna hulle soek, word die finale besluit ten opsigte van 'n spesifieke artikel in die winkel geneem en weinig kledingverbruikers besluit om meer inligting te soek of om weer oor die saak te dink. Veral die haastige en impulsiewe kledingverbruikers sal volgens Malherbe (1996:73) selde verder soek na meer inligting of ' $n$ besluit heroorweeg wanneer hulle 'n produk gevind het wat aan hul behoeftes voldoen. Eienskappe van die kledingstuk soos die prys, modieusheid, voorkoms en so meer en die verkoopsdame se opinie is die belangrikste faktore wat ' $n$ besluit tydens hierdie stadiums beïnvloed.

Navorsers oor kledingverbruik moet in gedagte hou dat nie alle verbruikers wat na inligting soek tydens die evalueringstadium dieselfde bronne raadpleeg nie en dus nie deur dieselfde faktore beïnvloed word nie. Modeleiers is meer geneig om geskrewe bronne van inligting, byvoorbeeld modetydskrifte, te raadpleeg asook professionele persone, byvoorbeeld voorkomskomsultante. Modenavolgers is meer gerig op oudiovisuele inligtingsbronne, byvoorbeeld televisieadvertensies, inligting by die aankooppunt, byvoorbeeld die verkoopsdame se opinie, of die opinies van die gesin en verwysingsgroepe.

Sproles en Burns (1994:275) glo dat faktore soos inkomste en onderwyspeil ook ' $n$ invloed uitoefen. Beter opgeleide kledingverbruikers asook dié in die hoërinkomstegroep en met hoërstatusberoepe is meer geneig om bykomende inligting te soek wanneer hulle oor kledingprodukte moet besluit. Dit bevestig Rousseau (1990:42 - 45) se siening dat verskeie persoonlike faktore asook in die omgewing die verbruiker se besluitneming beïnvloed. Ander navorsers wat hierby aansluit is Butler en Francis (1997) wat bevind het dat kledingverbruikers se besluitneming nie net deur algemene sosiale houdings beïnvloed word nie, maar ook deur die kultuurgroep en sosiale groep se houdings teenoor kleding as sodanig, terwyl die verbruiker se ouderdom en onderrigpeil ook ' $n$ invloed uitoefen. Figuur 5 illustreer Butler en Francis (1997) se stellings oor die verwantskap tussen hierdie faktore.

Dit duidelik dat invloede van buite, byvoorbeeld die kledingverbruiker se ouderdom en opleiding, 'n definitiewe invloed op sy of haar algemene lewenshoudings uitoefen. Hierdie invloede van buite het ook ' $n$ uitwerking op die omgewing se houding ten opsigte van kleding en uiteindelik ook op kledingaankoopgedrag. Net so beïnvloed verbruikers se algemene omgewingshoudings nie net hul houdings ten opsigte van kleding nie, maar ook direk hul kledingaankoopgedrag. Hierdie interverwantskap tussen invloede, houdings en aankoopgedrag moet in gedagte gehou word wanneer verskillende verbruikers se kledingaankoopgedrag ondersoek word. Dit is duidelik dat kledingverbruikers nie almal oor dieselfde kam geskeer kan word nie aangesien die besluitnemingsproses nie by almal dieselfde verloop nie en ook nie deur dieselfde faktore beïnvloed word nie.

Shim en Kotsiopulos (1993) en Shim en Bickle (1994) het op hul beurt bevind dat daar by die grootste persentasie kledingverbruikers simbolies instrumentele motiewe bestaan wat hulle aankoopbesluitneming beïnvloed. Kledingprodukte kan byvoorbeeld mense se selfbeeld ondersteun, hul rolle en status weerspieël en beroepsbeeld ondersteun. In aansluiting by Rousseau (1990) se siening asook die navorsing van Butler en Francis (1997), meen Cassill en Drake (1987) en Fast et al (1989) dat ouderdom, inkomste, opleiding en beroep belangrike invloede in die kledingverbruiker se besluitneming is. Dit bevestig die mening van Midgley (1983) dat besluitneming ten opsigte van verbruikersprodukte met ' $n$ hoë simboliese waarde, soos kledingprodukte, deur spesifieke verbruikersmotiewe beïnvloed word. En dit het weer tot gevolg dat die stadiums ten opsigte van inligtingsoeke en evaluering anders beïnvloed word en anders verloop as by produkte met 'n laer simboliese waarde. Morganosky (1987) meen dat veral modebewuste kle- 


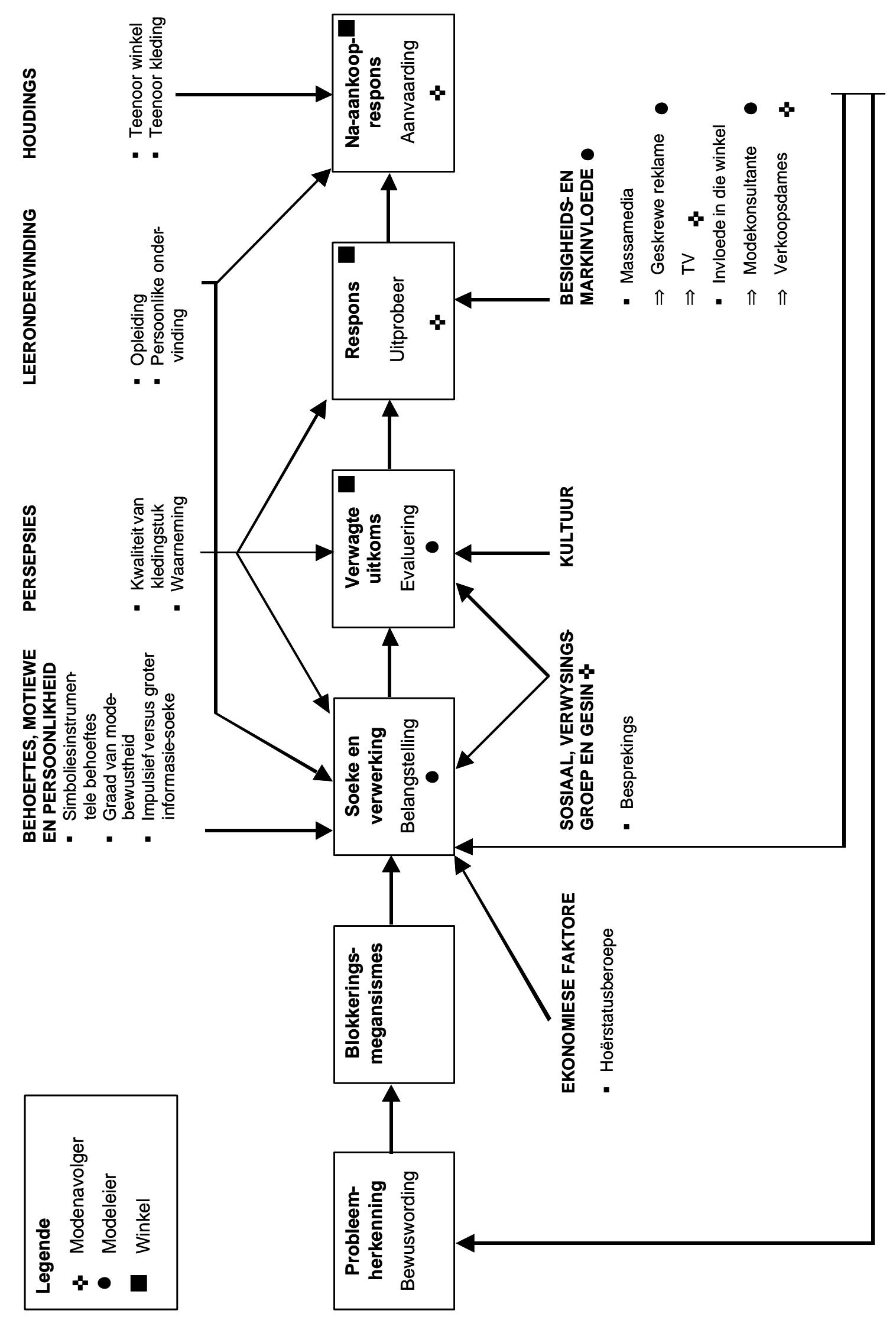

FIGUUR 6: GEİNTEGREERDE KLEDINGBESLUITNEMINGSMODEL 
dingverbruikers se besluite sterk deur estetiese waardes beïnvloed word. Dit gaan dus dikwels vir hulle nie om ' $n$ begeerde nuwe modeartikel nie omdat die artikel werklik noodsaaklik is. Kledingverbruikers met hoë estetiese waardes is ook geneig om kwantiteit bo kwa-liteit te verkies.

Met betrekking tot persepsies en die invloed wat dit op kledingverbruikers se besluitneming het, het Abraham-Murali en Littrell (1995) bevind dat kledingverbruikers bepaalde persepsies vorm oor die fisiese voorkoms van ' $n$ kledingproduk asook oor die gedrags- en ekspressiewe kwaliteite van die produk. Hierdie persepsies het ' $n$ definitiewe invloed op besluitneming. In aansluiting hierby stel Forsythe (1991) dat kledingverbruikers se besluitneming veral beïnvloed word deur hul persepsies van die kwaliteit van die produk. In teenstelling met baie ander verbruikers, ontstaan kledingverbruikers se persepsie van kwaliteit by die aankooppunt, hoofsaaklik na aanleiding van die eienskappe van die kledingstuk en nie noodwendig die handelsnaam nie. As hierdie inligting met Rousseau (1990:47) se model geïntegreer word kan dit soos in Figuur 6 voorgestel word.

Dit is duidelik dat kledingverbruikers se besluitneming deur ' $n$ verskeidenheid faktore beïnvloed word, waaronder houdings, persepsies, persoonlike behoeftes, besigheids- en markinvloede en die gesin, vriende en kultuur. Hierdie invloede is nie noodwendig vir alle kledingverbruikers dieselfde nie. Daar moet onderskeid gemaak word tussen die modeleier en die modenavolger. Dit is verder belangrik dat stadiums vier, vyf en ses hoofsaaklik by die aankooppunt plaasvind. Hier word kledingverbruikers ook beïnvloed deur faktore soos hul houding teenoor die winkel en die verkoopspersoneel, vorige ondervindinge met die produk of handelsnaam, die raad van verkoopspersoneel en advertensies.

Tydens die bewuswording- of probleemherkenning stadium speel besigheids- en markinvloede ' $n$ belangrike rol in kledingverbruikers se besluitneming. Die massamedia en geskrewe reklame soos brosjures of geskrewe advertensies in tydskrifte en invloede in die winkel of kledingprofessie, byvoorbeeld die opinie van ' $n$ modekonsultant, is belangrike bronne van inligting wat spesifiek die modeleier beïnvloed. Die modenavolger word ook deur die massamedia en invloede in die winkel beïnvloed, maar in hierdie geval deur televisieadvertensies of die opinie van die verkoopsdame. Hierdie inligting behoort vir die kledingnavorser sowel as die kledingbemarker van waarde te wees.

Geen inligting kon opgespoor word oor meganismes wat kledingverbruikers se besluitneming kan vertraag nie, waarskynlik omdat dit moeilik is om navorsing wat sterk op ' $n$ sosiaal-kognitiewe benadering steun deur te voer. Dié veld lê dus nog braak vir die kledingnavorser.

Volgens die model is dit duidelik dat kledingverbruikers se besluitneming tydens die belangstellingstadium, wanneer hulle veral inligting soek en verwerk, deur verskeie faktore beïnvloed word. Behoeftes, motiewe en persoonlikheid speel 'n belangrike rol. Daar is byvoorbeeld gevind dat veral die simbolies-instrumentele behoeftes van kledingverbruikers, byvoorbeeld dat klere status of bepaalde rolle moet uitbeeld, belangrik is. Modebewustheid en impulsiewe aankope speel ook ' $n$ rol. Verbruikers se persepsies beïnvloed besluitneming omdat hulle sekere kwaliteite van die kledingstuk beoordeel. Ondervinding is belangrik, byvoorbeeld opleiding en persoonlike ondervinding met ander en soortgelyke produkte.

Besigheids- en markfaktore soos die massamedia en die winkel self beïnvloed kledingverbruikers veral tydens die belangstellingsfase. Daar moet hier definitief onderskeid gemaak word tussen die modeleier en die modenavolger. Sosiale faktore in die omgewing, die gesin en die verwysingsgroep beïnvloed kledingverbruikers se besluitneming, byvoorbeeld wanneer belangstelling in ' $\mathrm{n}$ bepaalde kledingproduk met ander bespreek word.

Die model toon dat kledingverbruikers ook tydens die verwagte uitkoms- of evalueringstadium deur individuele en omgewingsfaktore beïnvloed word. Veral verbruikers se persoonlike persepsies het ' $n$ invloed, byvoorbeeld hul vermoë om sekere visuele leidrade in die kledingproduk te gebruik om 'n persepsie van die kwaliteit van die kledingstuk te vorm, of hul vermoë om vorige ondervinding in berekening te bring wanneer nuwe persepsies gevorm word. Kledingverbruikers se besluitneming word ook deur sosiale invloede, die gesin of verwysingsgroepe beïnvloed omdat ander se opinies in aanmerking geneem word wanneer ' $n$ kledingproduk geëvalueer word.

Dit is interessant dat kledingverbruikers tydens die respons- of uitprobeerstadium, wat meestal in die winkel by die aankooppunt plaasvind, hoofsaaklik deur besigheids- en markfaktore beïnvloed word. Op hierdie stadium het kledingverbruikers feitlik finaal besluit of hulle die produk gaan koop al dan nie en sal waarskynlik selde die besluit heroorweeg. Faktore wat by die aankooppunt ' $n$ invloed uitoefen, is die opinie van die verkoopsdame of bykomende inligting oor die produk, byvoorbeeld ' $n$ etiket aan die kledingstuk of " $n$ ander inligtingstuk soos ' $n$ brosjure of 'n advertensie.

Tydens die na-aankooprespons- of aanvaardingstadium sal kledingverbruikers se houding teenoor die produk asook hul houding teenoor die winkel 'n belangrike invloed uitoefen op die mate van tevredenheid met die produk en ' $n$ besluit om na die winkel terug te keer al dan nie.

Dit is uit bogenoemde duidelik dat ' $n$ geïntegreerde besluitnemingsmodel vir kleding met groot vrug in akademiese opleidingsprogramme gebruik kan word waar dit oor die gedrag van kledingverbruikers gaan. So ' $n$ model is ook waardevol vir navorsers in verbruikersgedrag en kledingverbruik. Bemarkers van kledingprodukte behoort ook die inligting van groot waarde te vind wanneer besluite rondom bepaalde verbruikersgroepe geneem moet word. 


\section{SIMBOLIESE INTERAKSIONISME EN ' $N$ KOGNITIEWE PERSPEKTIEF}

In die lig van menige navorsingstudie op die gebied van kleding gedurende die afgelope dekade is dit duidelik dat die simboliese interaksionisme en ' $n$ kognitiewe benadering sinvol gekombineer kan word om sekere sosiaal-sielkundige aspekte van mense se kledinggedrag te bestudeer. Dit stem ooreen met die siening van teoretici en akademici soos Kaiser (19831984), Davis (1984), Lennon en Davis (1989(a) en (b)), Nagasawa et al (1997), Damhorst (1991), Rudd (1991). Hierdie teoretici pleit vir ' $n$ kontekstuele benadering tot die bestudering van mense se kledinggedrag. Ongelukkig lyk dit asof min navorsers op die gebied van kledingverbruikerstudies en veral kledingverbruikersbesluitneming op Winakor (1981), Damhorst (1991) en Pannabecker (1997) se pleidooie vir groter eie teoriebou gereageer het. Dit spreek onder meer uit die feit dat van die nuwer handboeke op die gebied van mode en die kledingkleinhandel, soos die publikasies van Drake et al (1992) en Sproles en Burns (1994), nie eksplisiet en sterk genoeg op basiese sosiaal-sielkundige en kognitiewe perspektiewe soos die simboliese interaksionisme en 'n kognitiewe perspektief steun wanneer verbruikers se kledinggedrag bestudeer word nie. Ook in Suid-Afrika lê die veld braak en Velleman (1995) en Malherbe (1996) is van die weiniges wat verbruikersgedrag op die gebied van kleding vanuit hierdie perspektiewe benader het.

Die vraag is of die simboliese interaksionisme en 'n kognitiewe perspektief wel sinvol met ander gedragsteorieë gekombineer kan word wanneer kledingverbruikers se gedrag, in dié geval met verwysing na die besluitnemingsproses, bestudeer word. Hamilton (1997) voel sterk daaroor dat die simboliese interaksionisme moontlik nie die beste keuse is om sekere verskynsels op modegebied te verklaar nie. Kaiser et al (1997) verskil van Hamilton (1997). Hulle is van mening dat daar in die bestudering van die mode, óf uit die oogpunt van die produsent en kleinhandelaar óf dié van die verbruiker, eerder interdissiplinêr as bloot dissiplinêr uit ' $n$ kleding- of mode-oogpunt na sekere verskynsels gekyk behoort te word. In daardie geval sou die simboliese interaksionisme en 'n kognitiewe perspektief sinvol met die teorie ten opsigte van kleding of die verbruikerswese gekombineer kon word, mits die basiese uitgangspunte van die genoemde perspektiewe met verbruikersgedrag- en kledingteorie versoenbaar is. Navorsers soos Forsythe (1991) en Abraham-Murali en Littrell (1995) het bevind dat evaluering en konseptualisering (wat basiese kognitiewe prosesse is) belangrike aspekte in kledingverbruikers se besluitneming is. Dit impliseer dat ' $n$ kognitiewe perspektief nie geïgnoreer kan word wanneer die besluitneming van kledingverbruikers bestudeer word nie.

Die simboliese interaksionisme fokus sterk op die feit dat die individu, in hierdie geval die kledingverbruiker, gedurig in interaksie met ander mense is. Hierdie ander is betekenisvolle ander soos die gesins- of familielede, veralgemeende ander soos die breë gemeen- skap, mode en stereotipes, asook ander in die verwysingsgroep ander soos die groepe met wie die individu identifiseer. Hierdie mense het ' $n$ invloed op die individu se gedrag, onder meer op sy of haar persepsies of besluite omdat die individu hom-/haarself met ander vergelyk, sosiale terugvoering van hulle kry, hom-/haarself in die ander se skoene stel en hul persepsies aanvaar asook objekte uit die omgewing, byvoorbeeld kleding, as simbole vertolk soos ander dit doen. Al hierdie prosesse beïnvloed in ' $n$ mindere of meerdere mate die individu se gedrag, in dié geval sy of haar besluitneming (Charon, 1979:133-151). Die individu is ook in interaksie met die omgewing, in dié geval kleding as verbruikersproduk en die winkel waar die klere gekoop word en waar aspekte van die winkel hom of haar beïnvloed om ' $n$ bepaalde produk te koop al dan nie (Charon, 1979:133-150).

Die individu is egter ook in interaksie met hom-/haarself. Die simboliese interaksionisme stel dat die individu ' $n$ aktiewe, denkende wese is wat ook beïnvloed word deur perspektiewe, motiewe, gelowe, waardes, verwagtings en so meer wat hy of sy in die verlede aangeleer het en vanuit die verlede in ' $n$ bepaalde situasie indra (Charon, 1979:88-96). Hierdie verwa0gtings, idees en so meer het deel van die individu geword en kan sy of haar persepsies en uiteindelike besluite beïnvloed.

' $n$ Kognitiewe perspektief is gerig op menslike denke, veral op persepsies wat mense vorm. 'n Kognitiewe perspektief gee groter duidelikheid oor hoe betekenisse tydens interaksie gevorm word (Baron \& Byrne, 1987:36-65). Die feit dat mense rasionele, denkende wesens is, word sterk beklemtoon. Kognitiewe prosesse word gebruik om stimuli uit die omgewing te verwerk en te vertolk. Die realiteit is egter kompleks, met die gevolg dat mense dikwels kortpaaie vind om inligting te verwerk, byvoorbeeld by wyse van stereotipering in persepsievorming of deur sekere selfskemata, persoons- en rolskemata en gebeurlikheidskemata te vorm. Dié word dan vinnig opgeroep om op ' $n$ relatief eenvoudige en vinnige manier ' $n$ bepaalde prentjie te kan vorm (Baron \& Byrne, 1987: 94-97).

'n Belangrike fokuspunt van ' $n$ kognitiewe benadering is dat mense tydelike oorsake vir hul eie en ander se gedrag soek in ' $n$ poging om sekere persepsies van hulself en ander te vorm (Baron \& Byrne, 1987:39). Hierdie inligting word dikwels deur nieverbale leidrade oorgedra, byvoorbeeld by die aankooppunt in die winkel met verwysing na die verkoopsdame se voorkoms.

Volgens Baron en Byrne (1987:39) probeer mense ook om die langtermynoorsake van ander se aksies te voorspel en dit staan bekend as attribusie. As kognitiewe kortpad het dit ' $n$ invloed op die persepsies wat mense van ander, hulself en situasies vorm (Baron \& Byrne, 1987:47).

Die siening van die verbruiker vanuit die vertrekpunte van die simboliese interaksionisme en 'n kognitiewe perspektief word in Figuur 7 voorgestel. 


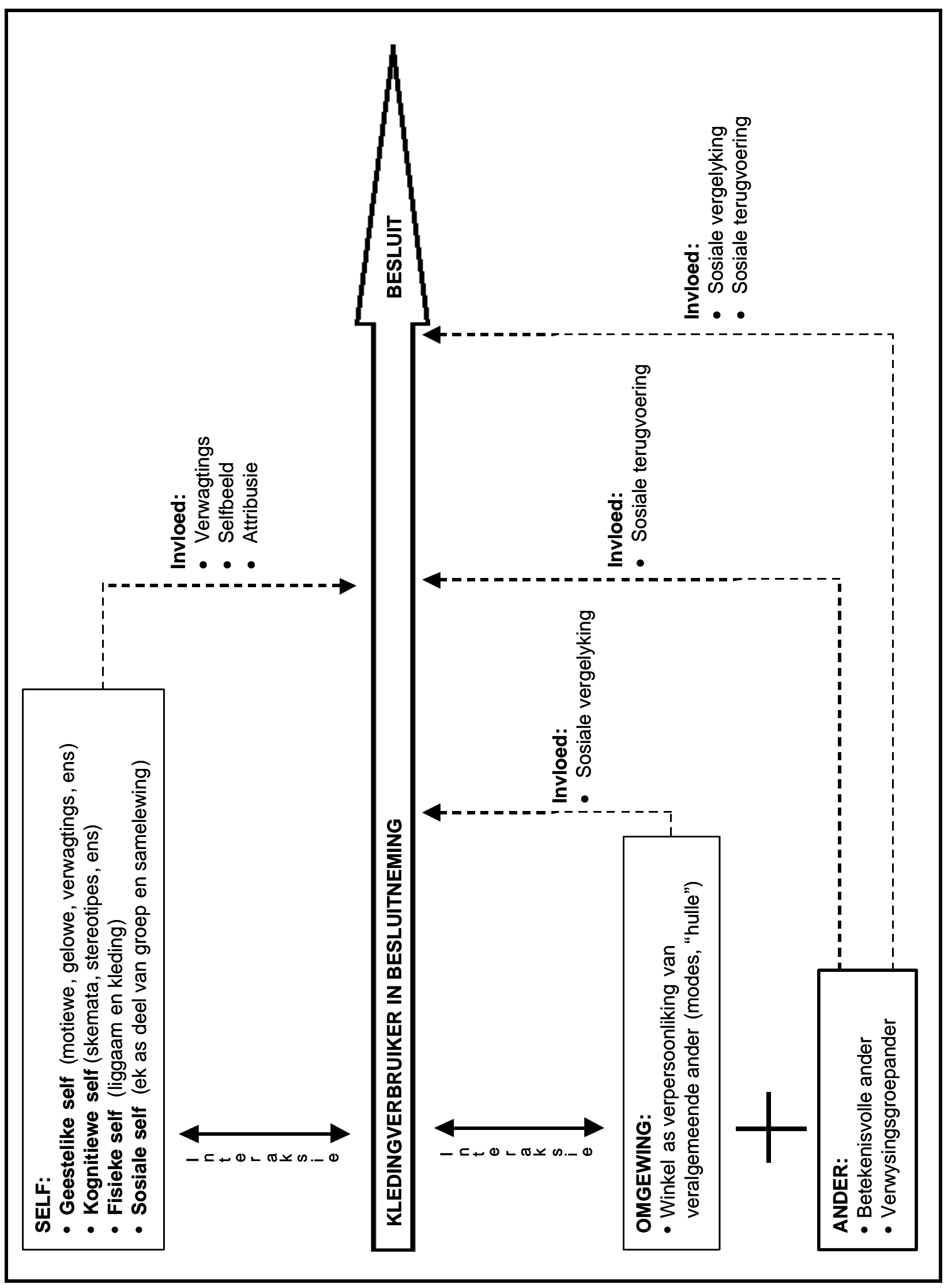

FIGUUR 7: DIE KLEDINGVERBRUIKER VANUIT 'N SIMBOLIES-INTERAKSIONISTIESE EN KOGNITIEWE PERSPEKTIEF 
Die model toon aan dat kledingverbruikers in " $n$ koopsituasie met hulself, die omgewing en ander in interaksie is. Die self waarmee hulle in interaksie verkeer, is die fisieke en materiële self wat die liggaam, kleding en algemene voorkoms insluit. Hulle is egter ook in interaksie met die sosiale en geestelike self wat aspekte soos geloof, motiewe, houdings en verwagtings insluit. Die omgewing waarmee hulle in interaksie is, is die kledingkleinhandel in die vorm van die winkel of beskikbare modes. Kledingverbruikers is ook in interaksie met 'n groot verskeidenheid ander:

- Betekenisvolle ander soos die gesin en familie op wie hulle veral sterk steun vir sosiale terugvoering oor hul voorkoms en kleding

- Veralgemeende ander in die vorm van die mode, stereotipes en die breë gemeenskap met wie kledingverbruikers hulself graag vergelyk

- Verwysingsgroep-ander wat die groepe insluit waaraan hulle behoort en graag wil behoort, op wie hulle sterk steun vir sosiale terugvoering en met wie hulle hul kleding en voorkoms graag vergelyk.

Die model toon ook duidelik dat kledingverbruikers skemata met betrekking tot hulself, ander en die omgewing vorm. Sommige van die skemata neem selfs bepaalde stereotipe vorms aan. Hierdie skemata asook die feit dat hulle graag die oorsake vir hul eie en ander se gedrag wil verstaan - waarvoor hulle die proses van attribusie en self-attribusie inspan - het telkens ' $n$ invloed op die persepsies wat hulle vorm en uiteindelik ook hul besluitneming.

' $n$ Verdere vraag sou wees of daar op dieselfde wyse na samelewings of groepe verbruikers se verbruikersbesluitneming gekyk kan word. Ten spyte van Hamilton (1997) se ongemak rondom die gebruik van die simboliese interaksionisme, voel Kaiser et al (1997) sterk dat daar wel uit 'n verbruikersinvalshoek na aspekte van die mode, in dié geval die verbruiker se besluit om 'n modeartikel te koop al dan nie, gekyk kan word. Volgens Charon (1979:154-155) is dit vanuit die simboliese interaksionisme nie nodig om onderskeid tussen verskillende tipes organisasies te maak nie, aangesien alle groepe uit individue bestaan wat in interaksie verkeer. Sosiale wêrelde word dus gevorm deur mense wat in simboliese interaksie met mekaar verkeer en in die interaksieproses dieselfde persepsies deel, wat in wese beteken dat hulle mekaar in hierdie interaksiesituasies in aanmerking neem. Blumer $(1966: 540)$ praat van "... fitting together their acts", "n "joint action" wat niks anders as die aanvaarding van ' $n$ nuwe mode is nie.

Tydens kledingverbruikersbesluitneming, waarby die verbruiker se self intens betrokke is en waar ' $n$ hoë sosiale risiko aan die koop van die produk verbonde is, word verbruikers dus deur lede van ander groepe asook die breë samelewing beïnvloed. Charon (1979:158) benadruk "society ... as individuals emerging in cooperative action", soos in die aanvaarding van ' $n$ nuwe kledingproduk of 'n soortgelyke be- sluitnemingsproses. Die groep of samelewing verskaf bepaalde perspektiewe maar ook veralgemeende ander met wie die individu hom-/haarself kan vergelyk, in hierdie geval modeprodukte of ' $n$ bepaalde skoonheidsideaal.

Charon (1979:173) stel dat wanneer verskynsels binne samelewings of groepe bestudeer word, dit in wese gaan oor die bestudering van individue wat die samelewing of groep uitmaak. Charon (1979:173) stel dit so: "People make society - society makes people". Aan die hand van hierdie siening kan daar dus sterk ten gunste van die simboliese interaksionsme in die bestudering van sekere aspekte van verbruikersgroepe se kledinggedrag geredeneer word. Hoewel Drake et al (1992:15-64) en Sproles en Burns (1994:179-212 en 263-279) dit nie so eksplisiet stel nie, steun hulle siening van verbruikersgedrag en spesifiek verbruikersbesluitneming wel op ' $n$ simbolies interaksionistiese uitgangspunt en ' $n$ kognitiewe benadering. Velleman (1995) en Malherbe (1996) bevestig in hul navorsing onder volwasse dames dat aspekte van kledingverbruikersgedrag wel sinvol vanuit die perspektief van die simboliese interaksionisme en ' $n$ kognitiewe benadering bestudeer kan word.

\section{'N MODEL VIR DIE BESLUITNEMING VAN KLEDINGVERBRUIKERS}

In die lig van die voorafgaande bespreking en die voorstellings in Figuur 1-7, bied die volgende model (Figuur 8) vir die student en navorser ' $n$ omvattende beeld van die wisselwerking tussen al die genoemde aspekte. Dit is duidelik dat kledingverbruikers tydens die verskillende stadiums van besluitneming deur ' $\mathrm{n}$ menigte persoonlike faktore asook faktore in die omgewing beïnvloed word. Hierdie faktore is nie vir kledingverbruikers noodwendig dieselfde as vir verbruikers van ander produkte nie en beïnvloed ook nie die kledingverbruiker op dieselfde wyse as vir ander verbruikers nie. Die besluitneming van kledingverbruikers kan dus nie sonder meer gelyk gestel word aan die besluitneming van verbruikers van ander produkte nie. Alle kledingverbruikers word ook nie noodwendig op diesefde wyse en deur dieselfde faktore beïnvloed nie. Die kledingverbruiker is ' $n$ verbruiker in eie reg en moet as sodanig bestudeer word en ook so in die kledingkleinhandel hanteer word.

Hoewel die model teen die agtergrond van bepaalde teoretiese raamwerke ontwikkel is en daar nog baie ruimte vir verdere navorsing op dié gebied is, kan dit tog nuttig wees vir die bestudering van kledingverbruikers se besluitneming in die algemeen of moontlik sekere aspekte daarvan. Die model wys duidelike leemtes met betrekking tot inligting en navorsing oor kledingverbruikers uit en behoort sinvol deur die voornemen-de navorser gebruik te kan word. Aan die ander kant behoort die kledingbemarker die model te kan gebruik om sinvolle bemarkingsbesluite rondom sekere kledingverbruikersgroepe te kan neem. 


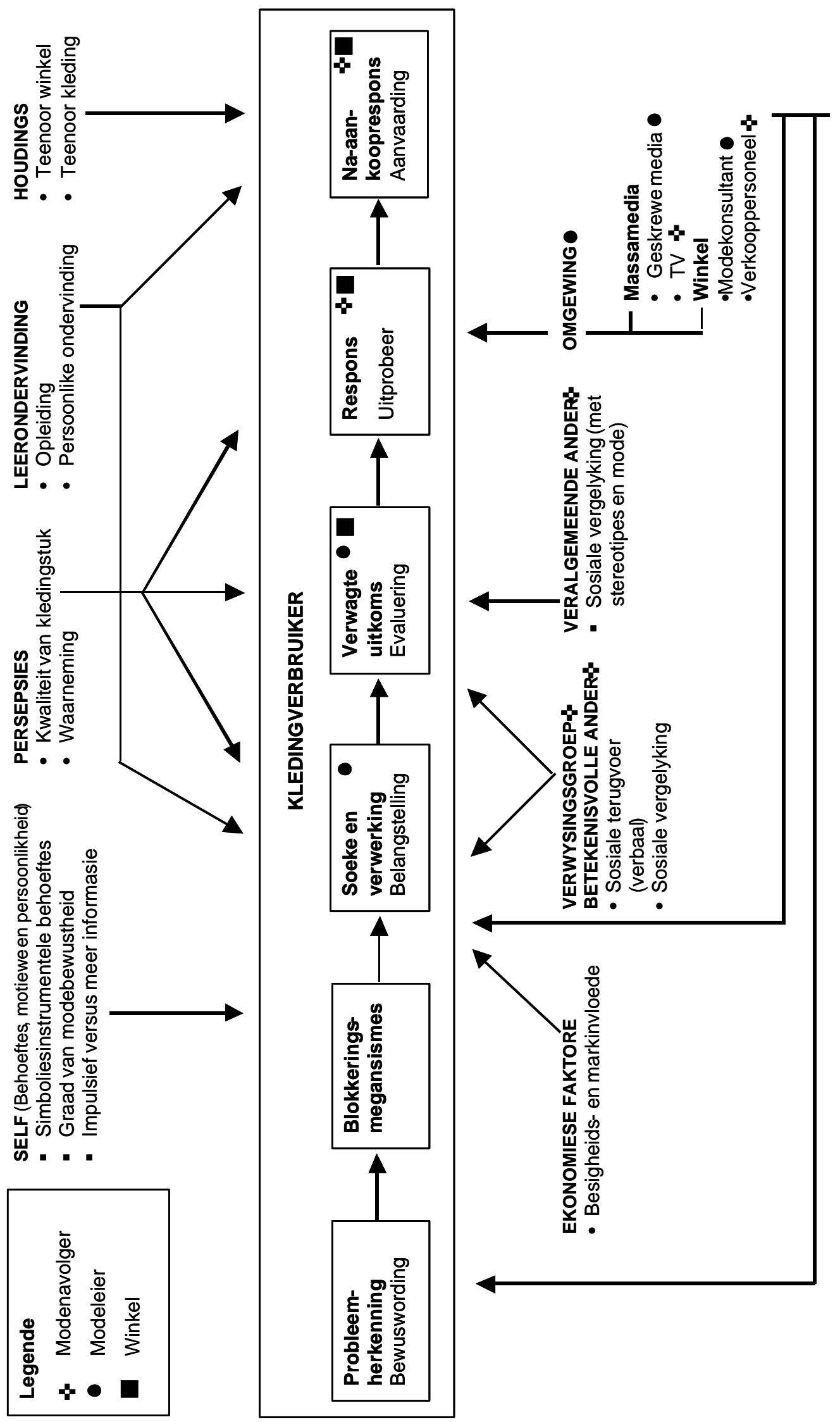

\section{FIGUUR 8: KLEDINGVERBRUIKERSBESLUITNEMINGSMODEL}




\section{VERWYSINGS}

ABRAHAM-MURALI, L \& LITTRELL, MA (1995): Consumers' conceptualization of apparel attributes. Cloth Text Res J 13(2):65-74.

ASSAEL, H (1987): Consumer behaviour and marketing action. 3rd ed. Boston. Kent.

BARON, RA \& BYRNE, D (1987): Social psychology: understanding human interaction. 5th ed. Boston. Allyn \& Bacon.

BLUMER, H (1966): Sociological implications of the thoughts of George Herbert Mead. Am J Social 71:534-544.

BUTLER, SM \& FRANCIS, S (1997): The effects of environmental attitudes on apparel purchasing behaviour. Cloth Text Res J 15(2):76-85.

CASSILL, NL \& DRAKE, MF (1987): Apparel selection criteria related to female consumers' lifestyle. Cloth Text Res J 6(1):20-29.

CHARON, JM (1979): Symbolic interactionism - an introduction, an interpretation, an integration. 2nd ed. Englewood Cliffs. Prentice Hall.

DAMHORST, ML (1991): Relation of textiles and clothing research to scientific inquiry in social cognition. ITAA Special Publication 4:191-202.

DAVIS, LL (1984): Clothing and human behaviour: review. Home Econ Res J 12(3):325-339.

DAVIS, LL (1987): Consumer use of label information in ratings of clothing quality and clothing fashionability. Cloth Text Res J 6:8-14.

DAVIS LL \& LENNON, SJ (1991): Social cognition and the study of clothing behaviour. ITAA Special Publication 7:182189.

DRAKE, MF, SPOONE, JH \& GREENWALD, H (1992 ): Retail fashion promotion and advertising. New York. Macmillan.

DU PLESSIS, PJ, ROUSSEAU,GG \& BLEM, NH (1990): Consumer behaviour. A South African perspective. Halfway House. Southern.

ECKMAN, M, DAMHORST, ML \& KADOLPH, SJ (1990): Towards a model of the in-store purchase decision process. Consumer use of criteria for evaluating women's apparel. Cloth Text Res J 2:13-22.

FAST, J, VOSBURGH, RE \& FRISBEE, WR (1989): The effects of consumer education on consumer research. $J$ Consum Aff 23(1):65-89.

FORSYTHE, SM (1991): Effect of private, designer, and national brand names on shoppers' perception of apparel quality and price. Cloth Text Res J 9(2):1-6.

HAMILTON, JA (1997): The macro-micro interface in the construction of individual fashion forms and meanings. Cloth Text Res J 15(3):164-171.

HORN MJ \& GUREL LM (1981): The second skin. 3rd ed. Boston. Houghton Mifflin.

KAISER, SB (1983-84): Towards a contextual social psychology of clothing. Cloth Text Res J 2:1-8.

KAISER, SB (1990): The social psychology of clothing. Symbolic appearances in context. 2nd ed. New York. Macmillan.

KAISER, SB, NAGASAWA, RH \& HUTTON, SS (1997):

Truth, knowledge, new clothes: responses to Hamilton, Kean and Pannabecker. Cloth Text Res J 15(3):184-191.

LENNON, SJ \& DAVIS, LL (1989a): Clothing and human behaviour from a social cognitive framework. Part 1 : Theoretical perspectives. Cloth Text Res J 7(4):41-48.

LENNON, SJ \& DAVIS, LL (1989b): Clothing and human behaviour from a social cognitive framework. Part 2: The stages of social cognition. Cloth Text Res J 8(1):1-9.

MALHERBE, E (1996): Die invloed van die verkoopsdame se voorkoms op die besluitnemingsproses van die verbruiker. Honneursprojek. Pretoria. Universiteit van Pretoria.

MIDGLEY, DF (1983): Patterns of interpersonal information seeking for the purchase of a symbolic product. J Market Res 20:74-83.

MORGANOSKY, MA (1987): Aesthetic, function and fashion consumer values: relationships to other values and demographics. Cloth Text Res J 6(1):15-19.

NAGASAWA, RH, KAISER, SB \& HUTTON, SS (1989):

Theoretical development in clothing and textiles: are we stuck in the concrete? Cloth Text Res J 7(2):23-31.

PANNABECKER, RK (1997): Fashioning theory: a critical discussion of symbolic interactionist theory of fashion. Cloth Text Res J 15(3):178-183).

POLEGATO, R \& WALL, M (1980): Information seeking by fashion opinion leaders and followers. Home Econ Res $J$ 8:327-338.

ROUSSEAU, GG (1990): The decision making process, in Du Plessis, PJ, ROUSSEAU, GG \& BLEM NH (eds). Consumer behaviour. A South African perspective. Halfway House. Southern.

RUDD, NA (1991): Textiles and clothing in higher education: strengthening linkages and conceptual identity. ITAA special publication 4:24-32.

SHIM, S \& BICKLE, MC (1994): Benefit segments of the female apparel market: psychographics, shopping orientations, and demographics. Cloth Text Res J 12(2):112.

SHIM, S \& KOTSIOPULOS, A (1993): A typology of apparel shopping orientation segments among female consumers. Cloth Text Res J 12(1):73-85.

SPROLES, GB \& BURNS LD (1994): Changing appearances. Understanding dress in contemporary society. New York. Fairchild.

VELLEMAN, AK (1995): Dames se gebruik van die klerewinkelaansig as simbool van bepaalde kenmerke. Honneursprojek. Pretoria. Universiteit van Pretoria. WINAKOR, G (1988): Research in fashion merchandising the need for a theoretical base. Cloth Text Res J 7(1):31-35. 